\title{
NEW TRENDS IN ITALIAN PRIVATE INTERNATIONAL LAW
}

\author{
Rodolfo De Nova \\ I \\ Historical ANTECEDENTS
}

To see in due perspective Italian developments in the field of private international law, both in theory and positive law, one has to start with the so-called Mancini school of the nineteenth century. ${ }^{1}$ As a side effect of the political ideology of the "nation," which was the driving spiritual force behind Italy's "Risorgimento"-and generally behind the political upheavals that took place in Europe after the Restoration was imposed by the Holy Alliance at Napoleon's downfall-a way out from the state of uncertainty and confusion in which the Statutists had left the subject of choice of law was found, in the second half of the last century, in the rejection of territorialism and the enthusiastic acceptance of the idea that law (private law) is a fundamental part of national life and as such is made for the citizen and, in principle, governs him even abroad.

In other words, the Italian patriot Pasquale Stanislao Mancini ${ }^{2}$ and his followers ${ }^{3}$ maintained that, by nature and history, people are grouped in different "nations," each one striving to become an independent State (if not already blessed by such a fullness of being, as was the case with France, the great model). For the time being, people belonged to the State-even if it was not the embodiment of their nation - to which they were attached by the legal bond of citizenship. In matters of private law, therefore, particularly those of a "personal" character, the citizens of a State were, as a rule, protected or directed by that State's law, which by right or sound reason, and possibly according to a general principle of international law, other States also were bound to apply to them: to their family relationships, for instance. On the other hand, in contractual matters the "autonomy of the parties" was asserted, as a consequence of the favor for "individual freedom" which was the liberal, or democratic, component in the movement for national reawakening that caused Italy

* Professor of International Law, University of Pavia, Italy.

${ }^{1}$ See, for instance, Fusinato, Il principio della scuola italiana nel diritto privato internazionale, 33

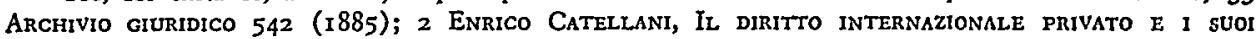
RECENTI PROGRESSI II8 (2d ed. I902); $i d$., LA DOTTRINA ITALIANA DEL DIRITTO INTERNAZIONALE NEL SEcolo XIX, 99 (1935); Diena, La conception du droit international privé d'après la doctrine et la pratique en Italie, 17 ACadémie de Drolt Internattonal, Recueil des Cours 347 (1927).

${ }^{2}$ See, e.g., Mancini, De l'utilité de rendre obligatoires pour tous les Etats, sous la forme d'un ou de plusieurs traités internationaux, un certain nombre de règles générales du droit international privé, I Journal dU Droit INTERnational 220 and 285 (1874). The Italian original of this essay (a report to the "Institut de Droit International") has been reprinted in 13 Diritto Internazionale 367 (I959).

${ }^{3}$ Inter alios, Pietro Esperson, IL pRincipio de nazionaltrá applicato alle relazioni civili internazionali, etc. (i 868); Giovanni Lomonaco, Trattato di diritto civile internazionale (i 874); Pasquale Fiore, Diritto internazionale privato (4 vols.) (4th ed. Igr3-1915); $i d$. . Elementi di DIRITTO INTERNazionale PRTVATO (I895). 
to become an independent, modern State. As to property, however, particularly real property, a certain authority was still conceded to the local law, the lex situs. And finally other matters, related to the hazy category of "public policy," remained under the sway of territorial rules, mainly those enacted by the lex fori. But notwithstanding these "exceptions" or concurrent principles, the leading principle, the "revolutionary" principle, was the competence of the lex patriae.

Mancini's ideas were influential in shaping the choice-of-law rules adopted by the Italian Civil code and by several foreign codes, and in inspiring or stabilizing modern decisional trends in civil law countries. However, after the initial enthusiasm and propagandizing, a reaction of the theorists soon set in, both in Italy and abroad. The tenets of the "Italian school" underwent an increasing amount of criticism where they had made headway, while they met only with cold indifference in common-law countries. More significant, however, than the debates on the interpretation of positive conflicts rules of Mancinian origin and on their value de lege ferenda for other countries or for international conventions, was the shift of interest that took place at the end of the century, particularly in Italian legal scholarship, to the "general theory" of private international law.

II

\section{The Theoretical Framework}

Mancini and his followers, by implication or avowedly, had envisaged the problem of conflict of laws as a problem of international relations: one set out or looked for universal principles by which the application of different bodies of national rules should be settled everywhere, thus solving the conflicts between national sovereignties as to the extent of the authority of their legal systems, particularly in matters of private law. By their persuasiveness, doctrinal views (those of the "Italian school," of course) were expected to find acceptance in the national legal orders-through statutes and court decisions-and even to inspire the crowning achievement of multilateral treaties. 5

But this international or universal approach soon ran into difficulties. The turn towards positivism, which marked European legal theorizing at the end of the nineteenth century, brought about the realization that, after all, private international law rules were far from identical in different States and could not, or could not all, be considered a part of international law. At the same time, the decline of natural law ideas had given rise to the need for a new explanation of the legal character of public international law and its relationship to internal law. Since the aim of private international law was taken to be the solution of interntional difficulties

' On the Italian rules of private international Iaw, as stated in the preliminary provisions to the civil code of 1942 (amending the code of 1865 , where art. 6-12 of the preliminary provisions dealt with conflict of laws), see the reliable account by McCusker, The Italian Rules of Conflict of Laws, 25 Tul. L. Rev. 70 (r950).

${ }^{5}$ The Hague conventions on private international law, the Montevideo treaties, and the Bustamante code were a partial response to that expectation. 
(by the choice of the "competent" law among competing and conflicting municipal laws), and since some of those rules were supposed to belong to the law of nations while most of them were clearly imbedded in the internal legal order of the several States, there arose a pressing need (a theoretical need, to be sure, but with some practical implications) to place private international law correctly in the general frame of the current view as to the relationship between national law and international law. ${ }^{6}$

\section{A. Anzilotti's Views}

The answer given to this question by the leading Italian jurist Dionisio Anzilotti (an answer he later disowned) ${ }^{7}$ was a shrewd compromise, one that seemed to fit exactly that slippery subject, private international law. Anzilotti starts from two assumptions: (I) that national law and public international law are "separate" legal orders ("dualistic theory"), so that a rule of public international law can be effective as to subjects of a State only in so far as it is transformed by the State itself into part of its own legal system; and (2) that choice-of-law rules, by solving conflicts of (national) laws, namely conflicts between national sovereignties, fulfill a task properly belonging to public international law, the law that governs the relationships between States. Private international law ought to be, therefore, a branch of public international law; there should be only one set of choice-of-law rules, binding all members of the international community. But, unfortunately, public international law is not as yet so perfect and complete as to provide a solution to all difficulties, large and small, arising from the coexistence of independent States. Confronted with "gaps," States must supply their own solution, which is effective as far as it goes, namely, as far as the authority of the State reaches. Such is the case for conflict-oflaws problems, according to Anzilotti. At the time-and this is still true-there were not enough choice-of-law rules of an international character: just a few general principles, at the most. Each State, therefore, had to do on its own what the international community had so far failed to do, namely, to solve conflicts of laws. As a result, we have as many national systems of private international law as there are States, and each is a substitute, for internal purposes, for the missing universal system of conflicts rules. In short, private international law is national law, but on an international subject matter: it is "Ersatz" international law.

Whatever the attractions and inconsistencies of this explanation, it marks the beginning of the keen interest shown by Italian students of private international law in the formal character, structure, and general purpose of this kind of legal rule, rather than in the interpretation, implementation, or criticism of the specific,

\footnotetext{
- See particularly Heinrich Triepel, Völkerrecht und LANDesRecht (1899), translated into Italian by Buzzati (1913).

T Dionisio Anzilotti, Corso di diritro internazionale privato 58 (1925). Anziloti was pro. fessor of international law at the University of Rome; he was also a judge at the Permanent Court of International Justice.

${ }^{8}$ Dionisio ANzilotit, Studi critici di diritto internazionale privato io4 (1898). For a recent acceptance of this view, see Werner Niederer, EINFührung IN DIE ALlgemeinen LeHren des internstionalen Privatrechts 442 (3d ed. 1961).
} 
'We do not mean to suggest that "practical" problems of private international law were and are utterly neglected in Italy. But, on the whole, legal scholarship has certainly been far more lavishly spent on theoretical difficulties. Perhaps this preference was due, at least in part, to the early codification of the subject matter and the scanty output of case law, not to mention the Italian university traditionstill extant - of teaching private international law and public international law as the two parts of a course on "international law."

Of late, partly as a reaction to excessive theorizing and partly thanks to a greater interest both in national and foreign statutory and decisional materials, there has been an increase in Italy of articles, essays, and books on the interpretation or ascertainment of positive rules and trends.

To cite at random, see: Giancarlo Venturini, Gli infortuni sUl Lavoro Nel DiritTo internazonale pRivato italiano (1940); De Nova, Problemi di diritto interlocale ed internazionale privato relativi ai territori annessi, I Comunicazioni e studi 129 (1942); GaEtano Arangio Ruiz, La cambiale Nel diritto internazionale privato (1946); Walter ZanNini, La ricerca della paternita' Naturale NEL DIRITTO INTERNazIoNaLe PRIVATO (I949); Migliazza, L'indegnità a succedere nel diritto internazionale privato italiano, 3 Comunicazioni E studi I97 (1950); Serra, La designazione della "lex contractus" (Art. 25 disp. prel.), 3 Comunicazioni E stud 177 (1950); Sperduti, Sulla capacita in diritto internazionale privato, con particolare rigtuardo alla capacità d'obbligarsi per fatto illecito, 4 Rivista iralians PER Le scienze giURIdiche (n.s.) 282 (1950); GIovanni Maria Ubertazzi, I rapporti patrimoniais tra coniugi nel dirtto internazionale privato (195I); De Nova, Appunti sullillecito civile in diritto internazionale privato comparato, 4 Comunicazion E studi 7 (1952); Migliazza, La divisione ereditaria nel diritto internazionale privato, 4 CoMunicazionI E STUDI 159 (1952); Malintoppi, La legge regolatrice della ricerca del genitore naturale ed il sistema del rinvio cumulativo, 36 RIvisTa DI oIRITTO INTERNazionale 386 (1953); Durante, La legge regolatrice della prova nel diritto internazionale privato, 37 Rivista DI diritto InTernazionale 494 (1954); Migliazza, La disciplina della forma degli atti di ultima volontì nel dirltto internazionale privato, 6 CoMUNICAZIONI E STUDI I8x (1954); ANTonio

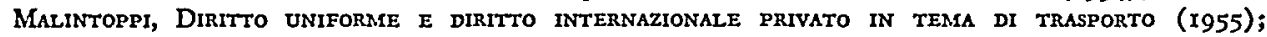
Giancarlo Venturini, Diritto internazionale privato: diritti reali ed obbligazioni (1956); De Nova, Esistenza e capacità del soggetto in diritto internazionale privato italiano, I ScRITT DI DIRITTo internazionale in onore di Tomaso Perassi 38I (1957); Quadri, Sulla legge applicabile alla "forma" dei negozi giluridici, 2 Scritt di diritro internazionale IN onore di Tomaso Perassi 233 (r957); Venturini, Note sulla disciplina di diritto internazionale privato delle obbligazioni da illecito, 2 ScRITTI di Diritto internazionale in ONORE di Tomaso Perassi 367 (x957); Quadri, La successione dello Stato nel diritto internazionale privato, 4 I RIvista DI DIRITTO INTERNAzIONALE 5I (I958); ROBERTo Socini, La filiazione Nel diritto internazionale privato (1958); Ruini, L'affiliazione nel diritto internazionale privato, 4 RIvisTa di pIRITTo cIvile 146 (1958); Cassoni, La procura nel diritto internazionale privato, 14 Diritto internazionale 256 (1960); Ferrari Bravo, Gli effetti delle condanne penali nel diritto internazionale privato italiano, 43 RIvista di DIRITTo InTERNazionale 26 (I960); De Nova, Considerazioni comparative stll'adozione in diritto internazionale privato, I2 Jus, RIVISTA DI screnze GIURIDIChe (n.s.) 255 (196I); De Nova, Adoption in Comparative Private International Law,

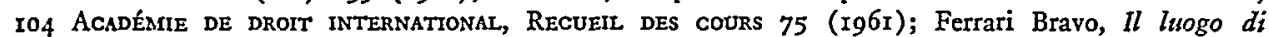
commissione dell'illecito nel diritto internazionale privato, 7 RIVISTA DI DIRITro cIVILE 80 (I96I); Ubertazzi, Il comportamento delle parti e la legge regolatrice delle obbligazioni contrattuali, I5 DiRItTo internazionale 201 (I96I); BenedetTo Conforti, L'esecuzione delle obBligazioni NeL DiRTtTo internazionale privato (I962); Ferrari Bravo, Aspetti generali della disciplina della responsabilitì per fatto illecito nel diritto internazionale privato, I7 ANNALI del. A FACOLTA' DI GIURISPRUDENZA DELI'UNIVersita' di Bari (ig62); Vincenzo Starace, La rappresentanza Nel diritTo internazionale privato (r962); Ubertazzi, Studi sul contratto di assicurazione nel diritto internazionale privato, I6 DiRITTo INTERNAZIONALE 3 I9 (I962).

Of course, in treatises and handbooks on the subject the "special part" receives due consideration (although, usually, in a somewhat stereotyped manner). Court decisions raising interesting points are reported and commented upon in "Foro Italiano," "Giurisprudenza Italiana," and other legal journals (notably the "Rivista di Diritto Internazionale"). Surveys of cases have been published in "Comunicazioni e Studi" and "Diritto Internazionale"; see also Udina, La législation et la jurisprudence italiennes en matière de droit international privé, de 1930 d 1934, 30 REvuE CRITIQUE DE DROIT Internatzonal 357 (1935); De Nova, La jurisprudence italienne en matière de confit de lois de 1935 d) 1949, 39 Revue Critroue de Droit International Privé 159 and 34I (1950). Several comments by Italian authors on Italian and foreign decisions on conflicts cases are to be found in the twelve-volume collection "Giurisprudenza Comparata di Diritto Internazionale Privato," edited from 1937 to 1956 by the "Istituto Italiano di Studi Legislativi" in Rome. 
Kelsen's "reine Rechtslehre," which had a great influence on Italian legal thinking, and similar trends in Italian jurisprudence, stressing the importance of "formal" problems of legal structure and classification, were responsible for the disproportionate amount of effort spent in Italy on the theoretical side of the subject. The nature, function, and mechanism of the "choice-of-law rule" have been the main subjects of research by Italian students of private international law since Anzilotti started playing the game.

\section{B. The Transformation Problem}

One line of inquiry was about the process by which a provision pertaining to a foreign private law becomes operative in the Italian legal order, and vice versa. Starting from the axiomatic presupposition that each State has its own discrete and independent legal order, Italian theorists were hard put to explain the application therein of rules belonging to another State's order, which appears to be the effect-or the most striking effect-of the rules on conflict of laws. That foreign law applied as such-either proprio vigore or under a grant of power by public international law -was contrary to the basic premise of the separation and self-sufficiency of each national legal order.

The way out of the dilemma was mostly found in the theory that national rules of private international law "nationalize" the private law rules of the foreign legal orders to which they refer. To explain in more technical terms this phenomenon of transfer and formal transformation of legal rules effected by the "choice" of a foreign law, some authors maintained that the choice-of-law rules themselves were empty frames that received their contents from the foreign legal systems which they declared to be "applicable" to the case (so-called "rinvio recettizio" or "rinvio materiale"). ${ }^{10}$ Later on, dissatisfied with that clumsy and grotesque image, other commentators favored the view that a choice-of-law rule, by pointing to a foreign legal order as the depository of the correct solution for the case at hand, recreates in its own legal order a provision homologous to the one that in the foreign system covers the relationship envisaged by the conflicts rule. ${ }^{11}$ A system of national private international law, therefore, activates a special process (an automatic one, according to Tomaso Perassi's last refinement) ${ }^{12}$ through which new rules are continuously created inside the legal order of the forum State by imitation, so to say,

\footnotetext{
${ }^{10}$ Marinoni, La natura giuridica del diritto internazionale privato, 7 RIvista DI DIRITTo INTERnazionale 346, 354 (igi3); Giovanni Pacchioni, Diritro Internazionale Privato i 6 (2d ed. x935).

${ }^{11}$ Ghirardini, Sull'interpretazione del diritto internazionale privato: Studi di teoria generale, 13 Ruvista di DiRitto internazionale 289 (I9I9); Roberto AGo, TEORA del DiRItTo internazionale PRIVATO II2 (I934).

122 Tomaso Perassi, Lezioni di diritto internazionale 62 (I938). Perassi was professor of international law at the University of Rome.

For a revision of the traditional concept of a "formal reference" ("rinvio formale") to explain the application of foreign law, see Balladore Pallieri, Le varie forme di rinvio e la loro applicabilita al diritto internazionale privato, 16 ANNUARIO dI DIRITTO COMPARATO E dI STUdI LEGISLATIVI 331 (1943).

See also Sperduti, Primi lineamenti di una teoria degli atti di normazione continuativa, 33 Ruvssta DI DIRITTO INTERNAZIONALE I4 (I94I); id., La produzione di norme giuridiche mediante rinvio al diritto stranieto, Le LegGi d'ItALIA (I946).
} 
of the legal provisions of those States to which each fact situation is connected by the link made relevant for that type of situation by the conflicts rule. In other words, a conflicts rule is a rule (of national law) that has the peculiar effect of setting up a special body of legal provisions to cover certain cases related to foreign countries and to foreign people.

\section{Unilateralism and Bilateralism}

Another effort of Italian theory in the last fifty years has been to "cleanse" the concepts of private international law of all lingering "residues" of the original nineteenth century public international law approach. Probably this goal has not been fully reached yet, and possibly it is not worth pursuing to the bitter end, because a lasting charm of the subject may be indeed its international flavor and appeal.

Be that as it may, the cleansing intent is particularly noticeable in the long-drawn discussion about the "function" of private international law. Does the typical choice-of-law rule, which states that the legal import-validity or effect-of a relationship connected to a "country" by a given "point of contact" will be assessed according to the law of that country, envisage both foreign law and the lex fori, or the former only, or only the latter? To use the current terminology, are conflicts rules "bilateral" or "unilateral," and, if they are unilateral, do they point inward or outward?

The traditional and, so to say, the pre-critical view has been that the application both of foreign and (at least sometimes, i.e., in case of doubt) of local rules depends on a choice made by private international law. Not so, it was objected: this is tantamount to making that branch of law-although avowedly national in character -into a sort of supernational system, hovering (another "brooding omnipresence in the sky"l) over all national orders, including - paradoxically-its own. Such a view, therefore, is a distorted reflection of the exploded theory which regarded conflicts rules as a part of the legal system that is indeed superior to States, and maybe to their legal orders too, namely public international law. To maintain, for instance, that Italian private law applies in Italy only in so far-at least in principle-as facts and relationships are connected to Italy by the connecting factors used by Italian choice-oflaw rules, exactly as French law applies in Italy when facts and relationships are connected to France according to the same Italian conflicts rules, is tantamount to asserting that a choice of laws must be carried out on a level superior to the legal system to which the choice-of-law rule itself belongs.

On the contrary, it is argued, from the point of view of each legal system, its own rules of private law are applicable per se; there is no need of a choice in favor of Italian law by the Italian conflicts rules to make it applicable in Italy. The purpose and function of Italian conflicts rules is only to give force of law in Italy to foreign rules, which otherwise would have no legal effect in the Italian legal system.

This opinion has been presented and upheld with great skill and care by 
Roberto Ago, in his Teoria del diritto internazionale privato. ${ }^{13}$ In this book the threads and patterns of previous doctrines have been interwoven, integrated, and logically developed, thus offering a very impressive statement of what one may still call the leading Italian theory of conflict of laws. As a matter of fact, all further work in the field as to fundamentals has been either directed to improve upon Ago's views, by adding further refinements or developments, ${ }^{14}$ or to criticize some of his conclusions and even to overturn his whole theory. ${ }^{15}$

The latter goal is attained by Rolando Quadri. ${ }^{18}$ After an independent and steady search for a more satisfactory explanation of some troublesome difficulties inherent in the subject matter, ${ }^{17}$ Quadri has just offered an imposing statement of his latest convictions, as a closely knit theoretical structure, in his Lezioni di diritto internazionale privato. ${ }^{18}$ Quadri's system-it is indeed a full-fledged system of thought-is both the most recent and the most original contribution to Italian conflicts theory, and deserves careful examination. At the moment, however, we shall merely point out that on the question of the "function" of private international law proper, namely, of State rules on the application of State law, Quadri opposes to Ago's opinion-that the raison d'être of conflicts rules is to make foreign laws applicable-a revised version of the early twentieth-century theory which holds that the rules of private international law simply or primarily establish when the private law rules of their own system apply.

On the other hand, in Ago's wake, and right after the publication of Ago's book, Giacinto Bosco advanced a middle-of-the-road theory. ${ }^{19}$ Assuming that choice-oflaw rules aim at governing "international cases," namely relationships connected with different legal orders, Bosco concluded that only cases having connections solely with the forum State come directly under the forum law, while cases that

${ }^{15}$ Op. cit. supra note $\mathrm{x}$. See also Ago, Règles générales des conflits de lois, 58 ACADEMIE DE DRoIr international, Recueil des cours 247 (1936). Ago is professor of international law at the University of Rome.

${ }^{14}$ See, e.g., Grorgio Cansacchi, Scelta e adattamento delle norme straniere richimate (1939); Rodolfo De Nova, Iz Richiamo di ordinamenti plurilegislativi (I940); Edoando Vitta, Conplitti INTERNI ED INTERNAZIONALI (2 vols., I954-1955).

${ }^{15}$ See, e.g., Piero Ziccardi, Il valore del diritto straniero neli' ordinameto nazionale (1946); Balladore Pallieri, I limiti di efficacia dell'ordinamento italiano, I JUS, RIVISTA DI SCIENZE GIURIDICHE I (1940); id., Drritto internazjonale privato (2d ed. 1950); Sperduti, Funzione delle norme di diritto internazionale privato e rilevanza interna degli atti stranieri d'amministrazione pubblica del diritto privato, 6 Rivista di diritto processuale 13 (I95I); Francesco Capotorti, La nazionalita' delle: societa' (I953); Piero Ziccard, Introduzione Critica al diritto internazionale (1956); Emilio Betti, Problemattca del diritto internazionale (1956).

${ }^{10}$ Professor of international law at the University of Naples.

${ }^{17}$ Quadri's earlier essays on private international law are collected in the first volume (the only one that has been published so far) of his STUdi CRITICI DI DIRITTO INTERNAzIoNALE (I958).

${ }^{18}$ Rolando Quadri, Lezioni di diritto internazionale privato (3d ed. ig6i).

${ }^{10}$ Giacinto Bosco, Corso di diritto internazionale privato (2d ed. 1939). Bosco is professor of international law at the University of Rome.

On the subject (and related questions) see also Biscottini, Osservazioni sulla funzione delle norme di diritto internazionale privato, 2 JUs, RIVISTA dI SCIENZE GIURIDICHE 415 (1941); GiovaNN1 PAU, Caratteri dez diritro internazionale privato (195x); Zancla, Sulla funzione delle norme di diritto internazionale privato, 15 AtTI deli'Accademis di Scienze Lettere ed ARTI di Palermo 321 (4th Series, 2d Part, 1953-54) (1955). 
are connected also with foreign States (besides having, necessarily, a link with the forum: otherwise they could not come up for decision there) depend for their legal evaluation on the rules of private international law of the forum, which will bring about the application to them either of a foreign law or of the lex fori itself. In other words, according to Bosco's (isolated) viewpoint, while foreign law always depends on private international law in order to be applicable, the lex fori is applicable per se to "wholly national" cases and is applicable by way of conflicts rules (including the public policy principle) to prima facie "mixed" (national-foreign) cases, because only the latter, and not the former, imply a conflict of laws, a doubt as to the applicable law.

\section{III}

\section{The Dominant Theory}

The safest and simplest way of summarizing the current views on the general problems of private international law in Italy is to follow the lead of the tiny but well executed "primer" by Gaetano Morelli, where the detailed discussion by Ago is synthetized and brought up to date for students' use. ${ }^{20}$

Choice-of-law rules, says Morelli, are rules of national law, and more precisely belong to public (constitutional) law, because they supervise the creation of special rules of private law, modeled on those of the "governing" foreign order, for the legal assessment of relationships with one or more "foreign elements." Their subject matter is social facts, but they govern these only indirectly, by choosing the (foreign) legal order that will supply the necessary provisions for their conclusive legal evaluation. As we already saw apropos of Ago's theory, the lex fori applies independently of any choice-of-law rule; it applies because it is there, as the private law branch of the national legal order. It may only be displaced by some special provisions of the same legal order, and precisely by those that are created according to the rules of private international law. As to the other main questions of a general import usually debated in the appraisal of the structure and functioning of conflicts rules-characterization, connecting factors, "renvoi," public policy, proof of the applicable foreign law-these are Ago's and Morelli's common conclusions:

Characterization, which is a necessary step for the determination of the apposite choice-of-law rule, has to be effected according to the lex fori. In other words, one "thinks away" the foreign contacts that raise a choice-of-law problem, and looks for

${ }^{30}$ Gaetano Morelli, Elementi di diritto internazionale privato italiano (7th ed. I962). Morelli is professor of international law at the University of Rome; he is also a judge of the International Court of Justice.

Other handbooks that follow, with individual variations, the general views stated by Ago are: Riccardo Monaco, L'efficacia della legge nello spazio (Diritto internazionale privato) (1952); Edoardo Vitta, Nozioni di diritto internazionale privato (3d ed. I960).

Earlier and comprehensive works that deserve mentioning are: 2 Giulio Diena, Principi di DiRItTo internazionale (2d ed. 19I7); Arrigo Cavaglieri, Lezioni, di Diritto internazionale privato (3d ed. 1933); Manlio Udina, ElementT di diritto internazionale pRivato italiano (1933); Scipione Gemma, Appunti di piritto internationale privato (x936); Prospero Fedozzi, II

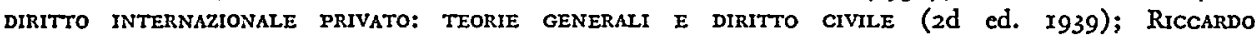
Monaco, Manuale di diritto internazionale pubblico e privato (I949). 
the rule that covers the case in the legal order taken as a starting point (lex fori). Then one inquires what conflicts rule makes use of the concept underlying that legal provision. The conflicts rule thus found will lead to the applicable foreign law through the connecting element which it uses. Finally, the foreign legal provision to be applied will be discovered by placing the relationship (stripped of any possible connection with legal orders different from the chosen one, if no "renvoi" is admitted, as is common opinion in Italy) in the perspective of the appropriate foreign legal order, a process that will require a "second characterization," to be carried out according to the same foreign law.

Connecting factors also require characterizing, as a rule; the exception being the situs of immovables, which is considered a mere fact, to be ascertained without reference to legal ideas and definitions. Here, too, characterization is made by the interpretation of the terms of reference of the choice-of-law rule in accordance with the lex fori. However, to substantiate the connecting factor of "nationality"-so important in Italian private international law-one looks at the nationality laws of each State. Should the propositus have dual nationality, the citizenship acquired by him for reasons more similar to those accepted by Italian law for granting Italian citizenship will prevail. Should he be stateless, a supplementary criterion will have to be established (in Italian law, it is residence).

As to "renvoi," it is logically unfounded. Apart from the usual objection that remission ("rinvio indietro") leads to a circulus inextricabilis, both remission and transmission ("rinvio oltre") contradict the purpose and power of the national rules of private international law to make a definite and autonomous choice of the applicable law.

Since the lex fori is the basic and potentially always the applicable law, whenever the foreign "competent" law is discarded because it would bring about a result contrary to the local "public policy," i.e., to some fundamental principle of the forum State's legal order, the case will be decided as if no foreign law were involved. The "exception of public policy" (an exception to the "normal" outcome of private international law, which is the application of some foreign law) is also called the "limit of public policy" ("limite dell' ordine pubblico") because, when a foreign rule is not "acceptable," the conflicts rule that would have led to its application in the forum is paralyzed (fenced in, so to say), and the lex fori takes over, as does the general law when no special rule stands in its way.

For the same reason, whenever the foreign applicable law is not available, particularly because its contents cannot be determined for want of pertinent and reliable information, the case will be decided on the basis of the lex fori.

As to the proof of foreign law, Morelli-who is the leading Italian specialist on the law of international civil procedure and jurisdiction ${ }^{21}$-maintains that the principle "jura novit curia" extends to foreign rules of law when these are transformed into national provisions by Italian choice-of-law rules.

${ }^{21}$ See Gaetano Morelit, Dirtto processule civile internazionale (2d ed. i954); id., Studi de DIRITTO PROCESSUALE CIVILE INTERNAZIONALE (I96r). 


\section{THE THeORY OF QuADRI}

Almost on all counts, Quadri differs. As already mentioned, he believes that rules of private international law, properly understood, merely relate to the legal order of which they are part. They are indeed an indispensable element of every rule of private law of every country, because they contribute to make it complete by fixing its scope, thus turning it into a real norma agendi-a prescription capable of affecting specific human behavior.

No State shapes its law as if the other countries did not exist and people had no relationships across their national borders. On the contrary, this obvious fact and the consequence thereof, namely, that human relationships often impinge on different communities at the same time, are taken into careful consideration everywhere. Hence States do not make their rules of law all-embracing. Just as they limit the validity of rules of law "in time" (by the rules of intertemporal law), so they limit their effect "in space." They specify, either within the rule itself ("norme autolimitate," Nussbaum's "spatially conditioned internal rules"22) or by adding a particular set of conditioning rules (the rules of private international law), to whom (citizens, domiciliaries, residents), to what acts (those done within the national boundaries, or aboard ships on the high seas carrying the national flag, and so on) and to what goods (those situated in the country, or in transitu therein, and so on) each version of their system of private law applies.

By the positive law approach, in order to know whether a fact of social life is regulated by a State's legal system, and, if so, what legal effects the latter attaches thereto, one must look at the "norms" of that legal system, namely, to its substantive rules plus the rules stating the conditions for their applicability, among which the conflict-of-laws rules are of decisive importance. Let us suppose that a case lacks those connections with the local community which the rules of private international law of that country require to make the local law applicable: for instance, the propositus is a foreigner, while to that sort of relationship the local law applies only when the parties are nationals of the forum State. Then, according to Quadri, it has to be determined whether some foreign legal order considers the case as falling within the scope of its own norms.

Should there be one, and only one, the solution that would be given by its norms to the problem under consideration will be given also in the legal order where the question arises (or in reference to which it is envisaged). There is, in fact, says Quadri, a general principle of law, operative in every modern legal system, according to which a State is ready and willing to include in its law rules modeled

"2 Arthur Nussbaum, Principles of Private Internattonal Law 72 (1943). On such rules see De Nova, I confitti di leggi e le norme con apposita delimitazione della sfera di efficacia, I 3 Dirrrro internazionale 13 (1959); id., Confits de lois et normes fixant leur propre domaine d'application, I Mélanges ofperts a JacQues Maury 377 (1960); id., Ancora sulle norme sostanziali "autolimitate," I3 Dirmtto internatronale 500 (1959); Graulich, Règles de conflit et règles d'application immédiate, 2 Mé́langes en l'honNeUR de JeAn Dabin 629 (1963). 
on foreign norms, whenever fact situations occur which its own norms-as conditioned by their rules of private international law-do not cover, while they are controlled by a foreign legal system. The foreign law applies on two conditions, then: a negative one, that the former law has no provision covering the case, because from its viewpoint, as stated by its rules of private international law, it is not sufficiently related to that national community; and a positive one, that according to its own rules of private international law, the foreign law "wants" to apply.

Characterization, in Quadri's theory, is always effected according to the conceptions of the legal order the possible application of which is envisaged, be it the lex fori or a foreign law. It is nothing more than interpretation.

No problem of "renvoi" arises, either, although foreign rules of private international law are to be followed too, precisely because the foreign law, exactly like the local law, applies only if it extends to the specific facts of the case, in view of its character and connections. Since private international law rules have a meaning only as a conditioning factor of the applicability of the other rules of their own system, the passage from the forum's legal order to a foreign one and then-through the latter's choice-of-law rules-back to the forum's law ("Rückverweisung") or forward to a third legal system ("Weiterverweisung") is not even conceivable. But on the other hand-contrary to the "no-renvoi" theory-neither is the application of foreign law dependent on the forum's "conditioning" rules (private international law) and independent from its own. It is exactly the opposite. The only, but basic and primary, intervention of the forum's private international law is aimed at establishing whether the lex fori has a rule of its own applying to the case.

Connecting factors are also fashioned by each legal system as an indispensable part of its rules of private international law and are operative as to their respective substantive rules. Their interpretation and ascertainment, therefore, depend on the views and purposes of the legal system using them. What is true of nationality, by common consent, is true of all connecting factors, in Quadri's theory, because they connect a relationship only to their own legal system, and it is unthinkable (or it would be plainly foolish) to resort to the views of any other order to define them and make them real, adequate to the purpose of the rule of private international law of which they are part. ${ }^{23}$

One should think that Quadri's approach would blur to extinction, as a separate concept, the idea of "ordre public." His theory, at least if it were carried over and thoroughly developed in positive law, seems bound to free private international law of that peculiar and elusive notion. He disparages the continental delusion (often unconscious) that the positive rules of private international law are those laid down by codes and statutes. He points out that these statutory rules are usually too broad, indefinite, ambiguous, and primitive to give due completeness to all substantive rules.

${ }^{28}$ The importance of the lex causae for the ascertainment of connecting factors is stressed, contrary to the common view, by Barile, Collegamento (Criteri di collegamento, dir. intern. priv.), 7 Enciclopedia DEL DIRrTro 350 (1960). See also Bentivoglio, Sulla natura dei criteri di collegamento utilizzati dalla norma di diritto internazionale privato, 8 CoMunicazionI E sTudi 143 (x956). 
Rather, the import and scope of the latter should be discovered (and already at present they often are, but surreptitiously) in the light of the purpose of those individual rules themselves and of the general policies of their legal order. But this, one would suppose, should be true also of certain principles that, at a given time, are considered to be fundamental in a country, even if they have not found expression in statutory enactments, or are only indirectly apparent. And according to Quadri, once we know that a relationship comes within the "reach" of a national rule (or principle), there is no question of looking at a foreign law. Therefore, the usual distinction between the refusal to apply a foreign rule because a national one applies and because, although the foreign law should prima facie be applicable, it must be set aside, as contrary to local "public policy," in favor of an unswerving principle of the forum's law, becomes meaningless.

Quadri indeed insists that-exactly as for the usual application of the lex fori-the public policy argument can be raised only when the case is materially connected to the forum State. And yet he does build a place apart for the principles affecting public policy, which, as such, apply even when "normally" a foreign law would and should apply. One might say that in Quadri's framework "ordre public" is really the "still unfinished part" of private international law: where private international rules are not yet specific enough, one must allow the play of a sort of general rule according to which local law also applies whenever it reflects a principle that, at the time, claims obedience even outside the limits set by the current rules of private international law.

Finally, Quadri disagrees with Morelli even with regard to the proof of foreign law, although both authors are agreed that foreign rules apply as "nationalized" rules, and both maintain that foreign law is never applied as such, but is only prelegal material for the creation of homologous national rules. But Quadri refuses to follow Morelli in equating, for that reason, national rules that are such, so to say, $a b$ origine, and national rules reflecting foreign ones. Precisely because the second type of rules are the fruit of a special technique of "adaptation," they may well be dealt with differently, for certain purposes, than those of the former type. There are indeed substantial reasons for doing so in the matter of proof. One cannot say, for instance, that judges are usually as well equipped to know foreign laws as they are to ascertain the content and import of their own. This is enough to make it appear more convenient that foreign laws be handled, in the matter of proof, more like facts than like legal rules, although it would be also unfortunate to equate them to mere facts. They are something in between, and as such deserve special treatment in court proceedings (particularly, judicial notice of some rules of foreign law could be taken more easily than is done with facts). ${ }^{24}$

We have seen that according to Quadri, when a legal order fashions a rule as covering a certain type of situation connected to that State in a certain way, that

${ }^{2}$ On this problem see, of late: Venturini, La prova del diritto straniero, 16 Diritto internazionale 312 (1962); De Nova, La prova del diritto straniero in diritto americano, id. at 299. 
rule will apply to situations of that kind in every other State too, unless the same situation, although connected with the first State, is placed by the rules of private international law of the second one, by stressing a different connection, under the provisions of the latter State. A law that "wants to apply" applies everywhere, unless it comes into competition with a lex fori that wants to apply as well. But quid juris when the lex fori is not interested, while the laws of two or more foreign States want to rule over the case? And what if conversely, no legal order claims to have legislative jurisdiction over a case that happens to be connected in fact only to States which treat those connections as immaterial? This is the well known difficulty encountered by previous "introvert" and "vested rights" theories of private international law.

Quadri tries to minimize the impact of the objection by assuring that the difficulty -particularly the so-called "negative conflict of laws"-will occur only seldom, and by counter-attacking with a list of difficulties encountered by the opponents in carrying out their own techniques of choice of law. He must recognize, however, that something is to be done to overcome the "impasse" facing his theory when there is competition between States, or, on the contrary, general indifference as to the legal regulation of certain relationships.

With a valiant respect for logic, Quadri makes his task particularly hard by refusing to enter the easy way out suggested by former explorers of the "unilateral" technique: ${ }^{25}$ to cut the Gordian knot by simply giving effect to any one of two or more competing legal systems, or, respectively, to fill the gap by twisting the forum's rules of private international law into rules able to effect also a choice among two or more "disinterested" foreign legal systems. This is sheer self-contradiction to Quadri. He falls back, instead, for the solution of the "positive conflict of laws," on two general propositions: the comparative effectiveness of legal rules, and the respect for the expectation of the interested parties as to the law governing their relationship. Accordingly, the forum will receive that foreign law which appears to be, in the circumstances of the individual case, the "proper law" (lex conveniens), the law having the more real connection with the transaction and on which the parties probably relied in their dealings.

How he proposes to solve a "negative conflict," a case of universal "desistment," is not so clear. This is indeed a tough dilemma. One might suggest, in the spirit of Quadri's system, that since no stated rule appears to be applicable here, each lex fori will fill the gap by creating new and apposite rules, possibly finding inspiration in the legal system that has a comparatively significant connection with the case. Quadri himself envisages the possibility that an "international case" require the creation of substantive rules ad hoc. He maintains, indeed, that when the character

${ }^{25}$ On these authors (Schnell and Niedner in Germany at the turn of the nineteenth century, Niboyet in France and Sohn in the United States in recent times, Pilenko in Russia around 1915 and later abroad), see Rudolf Wiethölter, Einseitige Kollisionsnormen als Grundlage des internationalen Privatrecits (1956). Sec also De Nova-Pilenko, Una corrispondenza su un nuovo metodo per la soluzione dei conflitti di leggi, 13 Diritto internazionale 98 (1959). 
of "public policy" affects an institution of the lex fori only partially, thus fragmentizing the foreign law adopted, and the case cannot be reasonably settled because both laws are thus crippled, one must turn to first principles and draw from them a special rule of decision.

\section{A Personal Conclusion}

- To close this survey on a personal note, I avow that writing it was for me more than an intellectual exercise: it meant going over my own efforts of thirty-five years to understand this baffling subject. Unfortunately, I have no solution of my own to offer (not yet!). I hope, at least, to have been a faithful and fairly clear ${ }^{26}$ expounder of the main trends and tenets-past and present ${ }^{27}$ - of the "Italian school" of private international law, to which I am proud to belong.

${ }^{26}$ Very likely, however, I was too rash to write in an acquired language on a subject that puts a strain on style even when using one's own mother tongue.

${ }^{27}$ For a more detailed examination and a very full bibliography, see the surveys that have been published in "Comunicazioni e Studi" by Pau and Malintoppi for I945-5I (Vol. 4, pp. 483 and 505, respectively), by Malintoppi for 1952-53 (Vol. 5, p. 499), by Bentivoglio for 1954-55 (Vol. 7, p. 439), by Ruini for 1956-57 (Vol. xo, p. 47x), and by Ballarino for 1958-60 (Vol. 11, in preparation). 